\title{
Challenges and Support for Parents of Children With Autism Spectrum Disorder at Work
}

Nurdiyana binti Laili, Wan Arnidawati Wan Abdullah, Hasnah Toran, Aizan Sofia Amin \& Roslinda Alias

To Link this Article: http://dx.doi.org/10.6007/IJARBSS/v11-i12/11804

DOI:10.6007/IJARBSS/v11-i12/11804

Received: 05 October 2021, Revised: 09 November 2021, Accepted: 26 November 2021

Published Online: 13 December 2021

In-Text Citation: (Laili et al., 2021)

To Cite this Article: Laili, N. binti, Abdullah, W. A. W., Toran, H., Amin, A. S., \& Alias, R. (2021). Challenges and Support for Parents of Children With Autism Spectrum Disorder at Work. International Journal of Academic Research in Business and Social Sciences, 11(12), 655-669.

Copyright: (c) 2021 The Author(s)

Published by Human Resource Management Academic Research Society (www.hrmars.com)

This article is published under the Creative Commons Attribution (CC BY 4.0) license. Anyone may reproduce, distribute, translate and create derivative works of this article (for both commercial and non0-commercial purposes), subject to full attribution to the original publication and authors. The full terms of this license may be seen

at: http://creativecommons.org/licences/by/4.0/legalcode

Vol. 11, No. 12, 2021, Pg. $655-669$

Full Terms \& Conditions of access and use can be found at http://hrmars.com/index.php/pages/detail/publication-ethics 


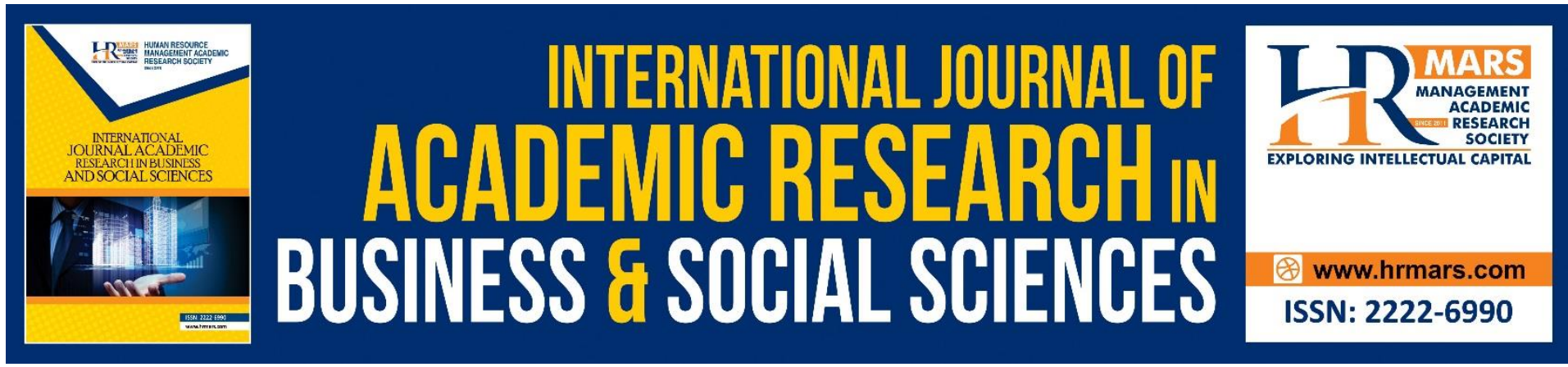

\title{
Challenges and Support for Parents of Children With Autism Spectrum Disorder at Work
}

\author{
Nurdiyana binti Laili ${ }^{1}$, Wan Arnidawati Wan Abdullah ${ }^{1}$, Hasnah \\ Toran ${ }^{2}$ Aizan Sofia Amin ${ }^{3} \&$ Roslinda Alias ${ }^{4}$ \\ ${ }^{1}$ Faculty of Human Ecology, Universiti Putra Malaysia, ${ }^{2}$ Faculty of Education, Universiti \\ Kebangsaan Malaysia, ${ }^{3}$ Faculty of Social Sciences and Humanities, Universiti Kebangsaan \\ Malaysia, ${ }^{4}$ Faculty of Education, Universiti Teknologi MARA \\ Email: arnidawati@upm.edu.my
}

\begin{abstract}
Generally, there is a public awareness that parents of children with autism syndrome disorder (ASD) face significant challenges in raising their children. This research aims to investigate the challenges and problems faced by these parents in the workplace. A qualitative study with purposive sampling was implemented. Three informants $(\mathrm{N}=3)$ were recruited from a family support group and went through an in-depth interview twice using a semi-structured format. The data were recorded, transcribed and analysed using thematic analysis. Among themes that emerged from the data were lack of exposure to ASD, peer views on parents of children with ASD, employer's concern for these parents, and cooperation between co-workers and parents of children with ASD. This study provides ideas and views for both employers and employees in Malaysia who deal with parents of children with ASD to guide workplace support and pull-down obstacles for these parents. This study is hoped to help the community, government agencies, and non-governmental organisations continue to pay attention to and assist parents of children with ASD in the workplace in order to raise awareness about ASD and encourage parents of children with ASD to continue working without worrying about childcare.
\end{abstract}

Keywords: Autism Spectrum Disorder, Disability, Workplace, Peers at Work, Organisational Support

\section{Introduction}

Autism Spectrum Disorder (ASD) is a complex developmental disorder characterised by persistent difficulties with social interaction, speech and nonverbal communication, and accompanied by restricted and repetitive behaviours. This disorder can be detected as early as 18 months of age, but it is commonly detected at the age of three (Paul \& Gilbert, 2011; Guthrie et al., 2012). It can be detected in behavioural differences and the unusual play that they joined. In addition, they have limited and repetitive behaviours as a coping mechanism, making it difficult for them to interact with people around them (Kanner, 1943). Without effective early intervention, a number of these children frequently display hyperactive behaviour and engage in self-harm. Due to these impairments, parents of children with ASD 
reported difficulties managing their children's behaviour, which impacts their caregiving process.

According to the Centers for Disease Control and Prevention (CDC), one in every 68 children in the United States has ASD, with boys being more commonly diagnosed than girls (Centres for Disease Control and Prevention, 2020). In Malaysia, about 9,000 children are born with ASD each year, and the current statistics recorded about 60,000 people are diagnosed with ASD (Anwar, 2016). ASD is not a psychological disorder; therefore, it should not cause social isolation from other children (World Health Organization, 2021). Currently, only one government agency, Genius Kurnia, provides early intervention services to children with ASD in Malaysia. Most children get the much needed therapeutic service from centres set up by non-governmental organisations or private entities.

It is not easy for parents to provide care and education for children with ASD. There are numerous challenges and obstacles that parents of children with ASD must overcome. The difficulties that these parents frequently face is related to care (Sharif \& Jamil, 2019). Most children with ASD require immediate parental attention because they require constant observation to ensure their safety. Therefore, it is not surprising that parents of children with ASD have a higher stress level than other parents because they face numerous challenges from various angles (Ali et al., 2020). According to previous studies, parents of children with ASD experience stress includes physical, emotional, and psychological aspects (Lee et al., 2017; Sharif, 2019; Takom et al., 2015; Takom et al., 2016). This psychological stress is exacerbated if the children have behavioural issues, which affects both parent and child (Manan et al., 2018; Mohamad \& Rosdi, 2018). Thus, positive community support is beneficial in providing moral support for parents during their struggles in raising their children (Ubeh et al., 2017). On top of this, environmental factors can also impact these parents' emotional and spiritual well-being.

Previous research on ASD has concentrated on the spiritual and physical support as well as challenges parents of children with ASD face in general (Zainun et al., 2019). The public is aware that there are numerous challenges for parents of children with ASD, especially for working parents, compared to non-working parents of children with ASD (Amin et al., 2016). However, limited research has focused on the support provided to parents of these children at work. Therefore, this study aims to investigate the challenges faced by parents of children with ASD at the workplace and explores on the support provided to working parents of children with ASD. This study tries to answer these research questions:

1. How well do colleagues understand the challenges faced by the parents of children with ASD?

2. What are the difficulties they face at the workplace?

3. Does the support and assistance from employers meet their needs?

The research findings are expected to increase future studies in this field, particularly in human development. Furthermore, this study is essential for developing knowledge systems, which could be used as the foundation for a study on challenges and support for parents of children with ASD. Furthermore, it is hoped that the findings could increase awareness for the 
government and the local community on the importance of support for parents of children with ASD.

\section{Autism Spectrum Disorder}

Autism Spectrum Disorder (ASD) is a highly complex developmental disorder diagnosed within the first three years of life (Santosa, 2003). The Diagnostic and Statistical Manual of Mental Disorders provides a guideline to identify these symptoms (DSM-V). Additionally, according to the World Health Organization (2021), ASD can be identified through a child's social interactions, relationships, and repetitive actions. Schriber et al (2014) correspond those children with ASD have distinct personalities and syndromes. However, as a child with ASD, the most inferred feature is difficulty communicating and social development. They usually enjoy isolating themselves and having creative thoughts away from others (Pearce, 2005). Many parents are concerned about their child's development since it appears to be slow in some areas, and it is not easy to assume that their child is average. Therefore, parents commonly consult with a psychiatrist to identify and treat their child's mental illness at the soonest (McConachie \& Diggle, 2007).

ASD is classified into three levels: mild, moderate, and severe. The first level depicts a child who works lightly but can still be controlled. Children with ASD can still behave generally at this stage. They can communicate and develop socially to a satisfactory level. Children can still control their ASD behaviour at this stage, but they can also express their wants and interests. Children at this stage are viewed as typical children, with typical attitudes and personalities. However, they had difficulty interacting and showed less in interactions with others. At this stage, parents, like everyone else, need to encourage and support their children constantly.

The second level is neither chronic nor acute, but they still require assistance in their daily lives. For example, a child with moderate ASD can still give a two-way response but has less response and learning than children with light levels. At this stage, ASD has difficulty communicating both verbally and nonverbally. They cannot say or hear what they want, but they can repeat words they hear or see.

The third level is aggressive ASD, which occurs when a child with ASD exhibits uncontrollable behaviour. Children at this level are in desperate need of much help. Children at this stage are classified as chronic because they have difficulty learning and communicating. It will have a significant impact on these children if they do not receive strong support. Children will become obsessed with an object at this stage and tantrum if it is taken or not given to them. Their tantrum is to self-harm without stopping or to bang their head against a wall. Aside from that, children at this age are preoccupied with their daily routine. They will have tantrums if their daily routine is changed, just as they would if they were obsessed with one object.

The Centers for Disease Control and Prevention (CDC) stated that the number of children diagnosed with ASD has increased for one world, with 1 in 150 children diagnosed with ASD in the United States in 2000, increasing to 1 in 59 children in 2014 (Maenner et al., 2020). This figure indicates that more than 3.5 million Americans have ASD. At the same time, it is reported that one in every 99 Malaysian children has ASD. 


\section{Challenges And Support for Parents of Children With ASD}

Having a child with ASD entails a significant amount of responsibility on the part of parents to ensure that the child receives the same level of affection as other children. Working parents of children with ASD would face physical, mental, and emotional challenges in caring for and raising a child with ASD. Some people chose to leave their jobs in order to devote their full attention to caring for the child. Working parents, according to Sitimin et al. (2016), struggle to strike a balance between their responsibilities at home and at work. Inability to manage both responsibilities due to an inflexible work schedule is a major factor for parents to resign. Parents of children with ASD need to create a more systematic pattern of care, in order to focus more on their children with ASD (Dieleman, 2018). This also aids in the care of their children with ASD, allowing them to adapt and be exposed to more social interactions.

According to previous research, moral and social support are two types of support provided to families of children with ASD. Agyekum (2018) defines social support as support from family and friends. Family support is essential to enable them to accept destiny and fate, which could reduce mental stress (Fhatri, 2019). If parents cannot accept their children's condition, they frequently experience chronic internal stress (Gentles et al., 2019). Therefore, the social system plays an essential role in motivating and improving positive attitudes in the parents of children with ASD in carrying out their daily routine (Sharif \& Jamil, 2019).

While for working parents, they receive two types of support at work that can help increase positive motivation: from their employers and their co-workers (Pinna et al., 2020). Employers and co-workers should support one another in the workplace for the benefit of both parties. According to Saidi et al. (2019), the organisational environment can meet individuals' needs and affect their satisfaction with the organisation. Accordingly, job satisfaction is critical in developing highly motivated and high-performing employees. Support from colleagues also assists parents of children with ASD in achieving a high quality of life. Rosli et al (2015) asserted that a colleague's responsibility is to assist in task completion by sharing work. This teamwork assists parents of children with ASD reduce stress and achieving job satisfaction due to conducive and comfortable working conditions.

In Malaysia, there is little flexibility for civil servants who have children with special needs. However, they can request permission to use working hours to care for their children if they have any needs. This permission could be used depending on the circumstances described in letter JPA (S) 1619 Klt. 11 (29) dated August 30, 2004. Furthermore, the government would allow any officials who have children with disabilities to work flexible hours to facilitate their children's welfare. It is critical to choose to arrive at work at 7.30 a.m. or 8.00 a.m. or 8.30 a.m. or 9.00 a.m., especially if the child has difficulties sleeping at night, wakes up late in the morning, and the parent wants to send them to school. On August 1, 2019, Service Circular No.5 declared the adoption of Flexible Working Hours (FWH), by which office hours are established from 7.30 a.m. to 6.00 p.m., except on Thursdays in Kedah, Kelantan, Terengganu, and Johor. However, in the private sector, it is up to the employer to grant any flexibility to their employees. 


\section{Methodology}

This study uses a qualitative technique in which data depicts observed human behaviour in spoken or written language (Wa-Mbaleka, 2019). According to Patton (1990, pp. 169-186).), this qualitative data is obtained from three sources of data:

i. Observation outcomes: detailed descriptions of situations, events, interactions, and observed behaviours during interviews;

ii. Discussion Outcomes: respondents' statements about their experiences, attitudes, beliefs, and responded thoughts during interviews; and

iii. Written content: Quotations or entire documents, correspondences, recordings, and anecdotes from the past.

Sampling is an essential technique for ensuring that the data is transparent and reliable. Therefore, purposive sampling, a non-probability sampling technique, was used to determine the samples for this study. The goal of sampling is to determine the number of samples involved based on specific criteria established by the reviewer. According to the criteria, the sample size is three people $(\mathrm{N}=3)$, all Malaysian working parents of children with ASD. Pseudonym names were used to replace original names. The profiles of the informants have been summarised in Table 1.

Table 1: Profiles of Research Informants

\begin{tabular}{lllcc}
\hline No & Name & Gender & No of Children with ASD & Age of Children with ASD \\
\hline 1 & Ani & Female & 1 & 9 \\
2 & Amin & Male & 3 & $11,10,8$ \\
3 & Fuad & Male & 1 & 8 \\
\hline
\end{tabular}

Following the current situation caused by the Covid-19 pandemic, the virtual interview was selected to collect data directly and accurately. As a result, the researcher conducted two (2) interviews with each informants using an interview guide asking about their background and obtaining information about support and challenges. Each interview session was conducted between 30 to 45 minutes.

As for the data analysis, the recorded interviews were transcribed and analysed using thematic analysis. This analysis method allows researchers to focus more on the responses and opinions of the informants and not deviate from the study's objectives. Important content through observations on informants was recorded during the interview session. This observation is a critical step to ensure that the researcher has a better understanding of the issue. It is necessary to make a directional sign to the review so that the study remains focused on generating a new theme.

Following the formation of the initial theme for each statement (See Table 2), the researcher then tried to find the association with the existing theme (See Table 3). Next, every respondent statement was refined to identify the meeting point used as a theme (Smith et al., 2009). For each respondent, this data analysis process was completed step by step. This process was generally repeated until the researcher could generate a theme for the data obtained and later identify the case equivalent pattern. 
Table 2: Sample of Early Theme Formation

\begin{tabular}{|c|c|c|c|}
\hline Line & Transcription & Interpretation & Initial theme \\
\hline 199 - & $\begin{array}{l}\text { This co-worker in terms of reception for the } \\
\text { family, has this special child as usual } \\
\text { because as I said emmm there may also be } \\
\text { my colleagues who have this special child, } \\
\text { so they also understand my situation. So I } \\
\text { don't feel awkward for work }\end{array}$ & $\begin{array}{l}\text {-Colleagues' } \\
\text { understanding of ASD } \\
\text { at work depends only } \\
\text { on the family } \\
\text { situation. For } \\
\text { colleagues who have } \\
\text { ASD children, they } \\
\text { understand the } \\
\text { situation experienced } \\
\text { by the informants. }\end{array}$ & $\begin{array}{l}\text { The co-worker's } \\
\text { understanding of } \\
\text { ASD is still lacking } \\
\text { because it } \\
\text { depends on the } \\
\text { situation }\end{array}$ \\
\hline $46-$ & $\begin{array}{l}\text { the main challenge may be in terms of } \\
\text { time. So we may err emm in terms of time } \\
\text { there may be some err constraints for us to } \\
\text { spend time with err child. Because errr for } \\
\text { example me, I work in afternoon sessions } \\
\text { and husbands also sessions so kids go to } \\
\text { school morning sessions. The kids went to } \\
\text { school in the morning session, but in the } \\
\text { evening he went to transit so there was } \\
\text { only night time. So there's very little time } \\
\text { for us to spend time doing ASD-related } \\
\text { therapy activities. }\end{array}$ & $\begin{array}{l}\text {-Challenges in } \\
\text { communicating with } \\
\text { ASD children due to } \\
\text { work factors }\end{array}$ & $\begin{array}{c}\text { Time } \\
\text { management }\end{array}$ \\
\hline
\end{tabular}

Table 3: Sample of Final Theme Formation

\begin{tabular}{|c|c|c|c|}
\hline Line & Interpretation & Initial theme & Final theme \\
\hline $\begin{array}{c}199 \\
- \\
202\end{array}$ & $\begin{array}{l}\text { Colleagues' understanding of ASD at } \\
\text { work depends only on the family } \\
\text { situation. For colleagues who have ASD } \\
\text { children, they understand the situation } \\
\text { experienced by the respondents. But not } \\
\text { for those who do not have ASD children }\end{array}$ & $\begin{array}{l}\text { The co-worker's } \\
\text { understanding of ASD is } \\
\text { still lacking because it } \\
\text { depends on the situation }\end{array}$ & $\begin{array}{c}\text { Lack of exposure to } \\
\text { ASD }\end{array}$ \\
\hline $\begin{array}{c}161 \\
- \\
163\end{array}$ & $\begin{array}{l}\text { Colleagues who quickly assess ASD } \\
\text { without looking at respondents' abilities }\end{array}$ & $\begin{array}{l}\text { Colleague's view of ASD } \\
\text { child's parent's work } \\
\text { performance }\end{array}$ & $\begin{array}{l}\text { Colleague's view of } \\
\text { ASD child's parents }\end{array}$ \\
\hline $\begin{array}{c}186 \\
- \\
188\end{array}$ & $\begin{array}{l}\text { The flexible schedule eases workload, } \\
\text { and respondents are more comfortable } \\
\text { to work }\end{array}$ & $\begin{array}{l}\text { Employer's concern for } \\
\text { ASD child's parents }\end{array}$ & $\begin{array}{l}\text { Employer's concern } \\
\text { for ASD child's } \\
\text { parents }\end{array}$ \\
\hline $\begin{array}{c}562 \\
- \\
587\end{array}$ & $\begin{array}{l}\text { The unending support made her happier } \\
\text { and responsible for doing the best for } \\
\text { her child }\end{array}$ & Partner support & $\begin{array}{c}\text { Cooperation } \\
\text { between ASD } \\
\text { partner and child's } \\
\text { parents }\end{array}$ \\
\hline
\end{tabular}


After obtaining the final theme (See Table 4), a complete table divided into themes and subthemes was established.

Table 4: Sample theme collection

\begin{tabular}{|c|c|c|c|}
\hline $\begin{array}{l}\text { Responde } \\
\text { nt }\end{array}$ & Interpretation & Initial Theme & Final Theme \\
\hline Ani & $\begin{array}{l}\text { Colleagues' understanding of ASD at work } \\
\text { depends only on the family situation. For } \\
\text { colleagues who have ASD children, they } \\
\text { understand the situation experienced by } \\
\text { the respondents. But not for those who } \\
\text { do not have ASD children }\end{array}$ & $\begin{array}{l}\text { The co-worker's } \\
\text { understanding of } \\
\text { ASD is still lacking } \\
\text { because it } \\
\text { depends on the } \\
\text { situation }\end{array}$ & \multirow[t]{2}{*}{$\begin{array}{l}\text { Understanding- } \\
\text { Lack of } \\
\text { exposure to } \\
\text { ASD }\end{array}$} \\
\hline Fuad & $\begin{array}{l}\text { He took the initiative to give exposure to } \\
\text { ASD to colleagues when the company } \\
\text { held activities with his family }\end{array}$ & $\begin{array}{l}\text { Lack of exposure } \\
\text { to ASD }\end{array}$ & \\
\hline Ani & $\begin{array}{l}\text { Colleagues who quickly assess ASD } \\
\text { without looking at respondents' abilities }\end{array}$ & $\begin{array}{l}\text { Colleague's view } \\
\text { of ASD child's } \\
\text { parent's work } \\
\text { performance }\end{array}$ & \multirow[t]{2}{*}{$\begin{array}{l}\text { Challenges- } \\
\text { Colleague's } \\
\text { view of ASD } \\
\text { child's parents }\end{array}$} \\
\hline Amin & $\begin{array}{l}\text { Still unable to control the child's } \\
\text { behaviour during tantrums and causes } \\
\text { much work to be delayed. } \\
\text { - The employer gives no flexibility in the } \\
\text { event of an emergency while he is } \\
\text { working }\end{array}$ & $\begin{array}{l}\text { Time management } \\
\text { - Employers are } \\
\text { less tolerant in } \\
\text { emergency cases }\end{array}$ & \\
\hline Ani & $\begin{array}{l}\text { The flexible schedule eases workload, and } \\
\text { respondents are more comfortable to } \\
\text { work } \\
\text { - More controlled child management }\end{array}$ & Employer support & \multirow[t]{3}{*}{$\begin{array}{l}\text { Employer's } \\
\text { concern for } \\
\text { ASD child's } \\
\text { parents }\end{array}$} \\
\hline Amin & $\begin{array}{l}\text { - The flexibility given by the employer } \\
\text { does not meet his needs in the event of } \\
\text { an emergency } \\
\text { - The employer did not support the } \\
\text { situation he experienced due to a lack of } \\
\text { communication to reach the point of } \\
\text { equality }\end{array}$ & $\begin{array}{l}\text { The flexibility } \\
\text { granted by limited } \\
\text { employers }\end{array}$ & \\
\hline Fuad & $\begin{array}{l}\text { - His caring employers made him feel } \\
\text { valued and not ignored }\end{array}$ & Employer support & \\
\hline Ani & $\begin{array}{l}\text { Assistance provided by colleagues helps } \\
\text { respondents to be more passionate about } \\
\text { living this life }\end{array}$ & $\begin{array}{l}\text { Colleagues } \\
\text { support }\end{array}$ & \multirow{2}{*}{$\begin{array}{l}\text { Cooperation } \\
\text { between } \\
\text { colleagues and } \\
\text { parents with } \\
\text { ASD children }\end{array}$} \\
\hline Amin & $\begin{array}{l}\text { - The tolerance among colleagues that } \\
\text { kept him going continued to work. } \\
\text { - Many colleagues gave her words of } \\
\text { encouragement and motivation to stay } \\
\text { strong in this life }\end{array}$ & $\begin{array}{l}\text { Cooperation } \\
\text { between partner } \\
\text { and parents with } \\
\text { ASD children }\end{array}$ & \\
\hline
\end{tabular}




\begin{tabular}{|c|l|l|l|}
\hline Fuad & $\begin{array}{l}\text { - Being surrounded by positive auras } \\
\text { makes him vital to raise a child } \\
\text { - The unending support made her happier } \\
\text { and responsible for doing the best for her } \\
\text { child }\end{array}$ & Colleague support & \\
\hline
\end{tabular}

Table 5 shows the final themes and sub-themes that were successfully released. Finally, the interpretation will be delved deeper by going through the transcripts obtained from each respondent.

Table 5: Theme Classification

\begin{tabular}{|c|c|}
\hline Final Theme & Sub-Theme \\
\hline $\begin{array}{l}\text { Understanding- } \\
\text { Lack of exposure to ASD }\end{array}$ & $\begin{array}{l}\text { - Colleagues' knowledge of ASD according to the } \\
\text { situation }\end{array}$ \\
\hline $\begin{array}{l}\text { Difficulties- } \\
\text { Colleague's views on parents } \\
\text { of ASD children }\end{array}$ & $\begin{array}{l}\text { - Judgemental on the work performance of ASD child's } \\
\text { parents }\end{array}$ \\
\hline $\begin{array}{l}\text { Support- } \\
\text { Employer's concern for ASD } \\
\text { child's parents }\end{array}$ & $\begin{array}{l}\text { - Provide flexible work schedules } \\
\text { - Give ASD child parents a bonus } \\
\text { - Understanding the situation experienced by parents of } \\
\text { ASD children }\end{array}$ \\
\hline $\begin{array}{l}\text { Support- } \\
\text { Cooperation between } \\
\text { colleagues and parents of } \\
\text { children with ASD }\end{array}$ & $\begin{array}{l}\text { - Care about the parent family of an ASD child } \\
\text { - Tolerance between co-workers and parents of ASD } \\
\text { children } \\
\text { - Provide support to parents of ASD children at work }\end{array}$ \\
\hline
\end{tabular}

\section{Discussion}

In understanding the study's findings, there are three critical aspects in developing themes: understanding of ASD among employers and colleagues at the workplace, difficulties faced by parents of children with ASD, and support received from employers and colleagues.

\section{Understanding of ASD among Employers and Colleagues at the Workplace}

Amin stated that his employer is still oblivious of his condition as the parent of three autistic children. Amin underlined that his life varies from other parents of children with ASD because all of his children have ASD. As a result, he found it difficult to manage his responsibilities as a father with his profession. Amin further stated that his employer did not comprehend his circumstances because he was not given any leeway in an emergency. Consequently, despite having three children with ASD, he must adhere to the company's policies. The employers' misunderstanding made him depressed, anxious and affected his work performance. He also stated that sometimes the stress he felt drove him to resign from his job and assist his wife with childcare and the family business he owned. Ani, on the other hand, stated that her coworkers' understanding of ASD is solely dependent on the family situation. Colleagues who have children with ASD can sympathise with the respondents' situation. Those who do not have ASD children, on the other hand, find it difficult to comprehend. However, for Fuad, he took the initiative to give exposure to ASD to colleagues when the company held activities with his family as to raise the awareness of ASD and the struggle he faced. 
It is understandable from this research that, despite numerous efforts by the government and various private sector organisations to raise public awareness about ASD, the message was not well received. Even with continual education concerning children with ASD, society is unaware of the whole spectrum of ASD. This finding supported the assertion of Nagarajah \& Nor (2019) that internet influences on the knowledge and awareness of ASD among the community is low. Many people still have a basic understanding of ASD and the challenges confronted by parents of children with ASD (Mohamad \& Rosdi, 2018; Rosli et al., 2015). As a result, ASD is still poorly understood in Malaysia, affecting the entire community. Parents of children with ASD still encounter negative preconceptions that make them uncomfortable and afraid to expose their children in public. The community's openness and curiosity regarding ASD are essential to increase parents' trust in their children with ASD. With the understanding, they will be more willing to reveal their child publicly without fear of social reaction.

\section{Challenges Faced by Parents of Children with ASD at the Workplace}

All of the informants struggled to spend time with their children and communicate with them because of their jobs. Ani mentioned that her coworkers tend to make a quick diagnosis of ASD and to associate the burden of having children with ASD with poor work participation. They have a propensity to pass judgement on the work of others. Amin, equally, stated that he has had time management issues because of his boss's intolerance, especially in emergency situations. Subsequently, he is still unable to control the child's tantrums, causing significant delays in work, and his employer provides no flexibility in the event of an emergency while he is on the job.

Notably, the stigma surrounding ASD affects both children and their parents. Parents of children with ASD are not immune to the sway of their co-workers' conflicting views. Colleagues worry that they do not even comprehend the situation and obstacles parents of children with ASD face, and they routinely criticise them in the workplace (Zakaria \& Tauhaid, 2018). For example, they were upset when co-workers consistently overestimated their work talents. With society's negative stigma around ASD, these situations contribute to parents being more silent and pressured.

Sitimin et al (2016) found that most working parents of children with ASD struggle to care for them owing to employment concerns. This struggle happens because employers do not accommodate them with any support. As a result, when emergencies arise concerning their children with ASD, parents struggle to cope. They will lose motivation and hope to continue working due to a work environment that routinely punishes and degrades their families. Hence, many working parents of children with ASD choose to leave or change careers to care for their children.

In an emergency involving children with ASD at work, the employer can help by allowing the parents to work from home. Employers will be comforted if they can demonstrate their concern for understanding the predicament parents of children with ASD confront at work. To find common ground, both parties should establish a collaborative communication environment. It is critical because, in addition to reinvigorating employees' desire to work in a pleasant and joyful workplace, the following areas of commonality help employers understand and appreciate the actual situation that parents with ASD children face. 


\section{Assistance and Support from Employers and Colleagues for Parents of Children with ASD}

Fuad described his life as a working parent of children with ASD as challenging. However, the consistent support of colleagues has fueled his enthusiasm and ambition to succeed in life. Despite pondering quitting his job to care for his children with ASD, co-workers frequently encouraged him with words of advice and support to continue his career adventure. The study revealed that excellent moral support from all parties, particularly at work, helps parents of children with ASD in their daily life. A pleasant organisational environment can meet the needs of people while also promoting organisational satisfaction. Such positive moral support encourages parents of children with ASD to be more assertive in coping with this test and increase their work performance. Working in a tranquil environment will make these parents happier and more at ease. Mutual aid among co-workers is another sort of support provided to parents of children with ASD at work.

While for Ani, challenges are associated with juggling her profession and childcare. Having a kid with ASD causes many changes in a parent's life (Sharif et al., 2019). They must make decisions about priorities in terms of children and careers. Nonetheless, she intensely loves pursuing her chosen area because of her colleagues' tremendous support. Ani is grateful to be surrounded by colleagues who never stop giving her words of encouragement and a positive aura. The co-workers' support and help have injected enthusiasm in her to stay in her job.

These findings are consistent with previous studies, which stated that positive support from employers and co-workers to parents of children with ASD helps reduce the negative stigma of ASD-related society and allows parents of children with ASD to expose their children in public and live in the community. Similarly, Amin et al. (2016) asserted that giving psychological support to parents of children with ASD establish mutual understanding. Thus, the psychological assistance to the working parents of children with ASD is equivalent to providing moral support and motivating words to create confidence and excitement.

Furthermore, support from employers and co-workers plays a role in increasing informants' enthusiasm and desire. The openness, sympathy, and concern shown by co-workers for their family's situation are much appreciated. They are more optimistic about moving forward in life for the sake of their family and children because of the support provided. Their stress level also decreases with the work-partnerships in carrying out obligations offered by their colleagues. The conducive and comfortable working conditions also increase job satisfaction and help establish a positive attitude in parents of children with ASD, inspiring them to enhance their work performance despite having children with ASD. Instead, having children with ASD motivated them to enhance their work performance to provide a decent quality of living for the family.

\section{Conclusion}

It is understood from the findings that ignorant of the meaning of ASD lead parents of children with ASD to confront tremendous obstacles. Challenges in terms of work quality, time, and understanding co-workers due to these parents' situations make them feel unhappy and hopeless. However, the informants do not feel left out of a more open and friendly work environment. On the contrary, these parents believe that their presence is valued. A positive environment enhances parents' drive in their careers and their family's self-confidence. 
Despite the numerous hurdles, the most overwhelming is the community's skepticism concerning ASD. The performance and capacities to work among parents of children with ASD have little bearing on their children with ASD. However, their work is superior to that of other typical parents. Thus, there should be no negative perceptions of these parents' work performance.

The study implies that not all companies are sensitive to their role in employee welfare, especially for workers who have children with ASD. Companies do not consider even though the government offers exemptions and incentives to working parents of children with ASD. Caring and tolerant employers will make parents of children with ASD feel happy and more at ease, increasing their confidence in emphasising the performance and quality of their job. On the other hand, the unhappy parents with limited support will become worried due to the following predicament and may abandon their jobs due to poor performance. Therefore, it is hoped that all parties involved will promote awareness regarding ASD, particularly in the workplace. In addition, the media must consistently spread the word about ASD to create awareness across all sectors of society in Malaysia and around the world.

This study is expected to guide workplace support and challenges for parents with ASD children. For example, every employee should strive for a high level of job satisfaction to maintain their emotional well-being and succeed in an organisation. As a result, the organisation's support is heavily emphasised for these parents to have higher job satisfaction and child management. Finally, it is hoped that this study will help the community, government agencies, or non-governmental organisations continue to pay attention to and assist parents of children with ASD in the workplace to raise awareness about ASD and encourage parents of children with ASD to continue working without worrying about the childcare of their children with ASD.

All stakeholders, including extended relatives, siblings, neighbours, and employers, must provide constructive support to parents of children with ASD since their stress levels are higher than those of a typical parent (Lee et al., 2017). The experience shared by the informants strongly supported this statement. Employees in an organisation are no exception for providing support and assistance to parents of children with ASD at work. A good work atmosphere and cooperative spirit help to reduce the difficulties faced by these parents. However, caregiving stress will be at an all-time high if the professional sector cannot accept parents of children with ASD.

\section{References}

Agyekum, H. A. (2018). Challenges and coping strategies for parents with autistic children. Journal of Mental Disorder and Treatment, 4(3).

Ali, M. M., Ismail, N. F., \& Ismail, M. (2020). Meneroka cabaran yang dihadapi oleh ibu dalam menguruskan anak berkeperluan khas (Exploring the challenges faced by mothers in managing children with special needs). Journal of Quran Sunnah Education \& Special Needs, 4(2), 63-75.

Amin, A. S., Manap, J., \& Akhir, N. M. (2016). Peranan keluarga dalam kehidupan kanak-kanak kurang upaya Malaysia (The role of family in the lives of disabled Malaysian children). Akademika, 86(1). 
Anwar, Z. (2016). Education Ministry drafting a policy to address learning disabilities. https://www.nst.com.my/news/2016/04/137004/education-ministry-draftingpolicy-address-learning-disabilities

Centres for Disease Control and Prevention. (2020). CDC estimates 1 in 68 children has been identified with autism spectrum disorder. https://www.cdc.gov/media/releases/2014/p0327-autism-spectrum-disorder.html

Dieleman, L. M., Moyson, T., De Pauw, S., Prinzie, P., \& Soenens, B. (2018). Parents' Needrelated Experiences and Behaviors When Raising a Child with Autism Spectrum Disorder. Journal of Pediatric Nursing, 42,26-37.

Fhatri, Z. (2019). Perspektif orang tua terhadap anak ASD dan peranannya dalam terapi (Studi Kasus PLA Provinsi Kepulauan Bangka Belitung) (Parents perspectives of their children with ASD and their roles in therapy). Al-Mudarris (Jurnal Ilmiah Pendidikan Islam), 2(2), 154-169.

Gentles, S. J., Nicholas, D. B., Jack, S. M., McKibbon, K. A., \& Szatmari, P. (2019). Parent engagement in autism-related care: a qualitative grounded theory study, Health Psychology and Behavioral Medicine, 7(1), 1-18.

Guthrie, W., Swineford, L. B., Nottke, C., \& Wetherby, A. M. (2013). Early diagnosis of autism spectrum disorder: stability and change in clinical diagnosis and symptom presentation. Journal of Child Psychology and Psychiatry, and Allied Disciplines, 54(5), 582-590.

Kanner, L. (1943). Autistic disturbances of affective contact. Nervous Child, 2(3), 217-250.

Lee, J., Ong, S., Lee, V., \& Fairuz, N. (2017). Parenting Stress among Malaysian Parents of Children with Autism Spectrum Disorder (ASD). Medicine and Health, 12(1), 42-55.

Baio, J., Wiggins, L., Christensen, D. L., Maenner, M. J., Daniels, J., Warren, Z., ... \& Dowling, N. F. (2018). Prevalence of autism spectrum disorder among children aged 8 years autism and developmental disabilities monitoring network, 11 sites, United States, 2014. MMWR Surveillance Summaries, 67(6), 1.

Malaysia. Jabatan Perkhidmatan Awam. (2020). Cuti Rehat Khas Pegawai Perkhidmatan Pendidikan. Pekeliling Perkhidmatan Bilangan 8 Tahun 2017 (No.223543). https://docs.jpa.gov.my/docs/pp/2017/pp082017.pdf

Manan, A. I. A., Amit, N., Said, Z., \& Ahmad, M. (2018). The influences of parenting stress, children behavioral problems and children quality of life on depression symptoms among parents of children with autism: preliminary findings. Jurnal Sains Kesihatan Malaysia (Malaysian Journal of Health Sciences), 16.

McConachie, H., \& Diggle, T. (2007), Parent implemented early intervention for young children with autism spectrum disorder: a systematic review. Journal of Evaluation in Clinical Practice, 13, 120-129.

Mohamad, M. S., \& Rosdi, N. N. A. (2018). Hubungan antara tingkah laku keibubapaan, tekanan psikologikal dengan tahap kesihatan mental dalam kalangan penjaga kanakKanak ASD (Relationship between parenting skills, psychological distress with mental health level among caregivers of ASD children). Jurnal Psikologi Malaysia, 32(4).

Sharif, M. H., \& Jamil, N. A. (2019). Cabaran Ibu Bapa Bersama Kanak-Kanak Kecelaruan Spektrum Autisme (ASD): Tinjauan Literatur. Malaysian Journal of Social Science, 4(1), 33-43.

Mostafa, M. H., (2019). Stress and Coping Strategies among Parents of Children with Autism Spectrum Disorder. PEOPLE: International Journal of Social Sciences, 5(1), 17-29. 
Nagarajah, K. S., \& Abdullah @ Mohd. Nor, H. (2019). Pengaruh internet terhadap pengetahuan dan kesedaran tentang ASD dalam kalangan dewasa awal (Internet influences on the knowledge and awareness of ASD among new adults). Jurnal Wacana Sarjana, 3(4), 1-12.

Patton, M. Q. (1990). Qualitative evaluation and research methods. SAGE Publications, inc.

Paul, R., \& Gilbert, K. (2011). Development of language and communication. Textbook of autism spectrum disorders, 147-157.

Pearce J. M. (2005). Kanner's infantile autism and Asperger's syndrome. Journal of Neurology, Neurosurgery, and Psychiatry, 76, 205.

Pinna, R., De Simone, S., Cicotto, G., \& Malik, A. (2020). Beyond organisational support: Exploring the supportive role of co-workers and supervisors in a multi-actor service ecosystem. Journal of Business Research, 121, 524-534.

Rosli, H. F., Sabri, S. A., Wahab, N. A., \& Zakaria, N. A. (2015). Kesedaran golongan majikan terhadap orang kurang upaya di Malaysia: Melalui perspektif media (Awareness of employers towards people with disabilities in Malaysia: Through a media perspective). Proceeding of the 2nd International Conference on Management and Muamalah.

Saidi, N. S. A., Michael, F. L., Sumilan, H., Lim, S. L. O., Jonathan, V., Hamidi, H., \& Ahmad, A. I. A. (2019). The relationship between working environment and employee performance. Journal of Cognitive Sciences and Human Development, 5(2), 14-22.

Santosa, S. (2003). Peran metallothionein pada autisme. Maranatha Journal of Medicine and Health, 2(2), 148027.

Schriber, R. A., Robins, R. W., \& Solomon, M. (2014). Personality and self-insight in individuals with autism spectrum disorder. Journal of personality and social psychology, 106(1), 112.

Sharif, M. H. M., \& Jamil, N. A. (2019). Cabaran Ibu Bapa Bersama Kanak-Kanak Kecelaruan Spektrum Autisme (Asd): Tinjauan Literatur. Jurnal Sains Sosial: Malaysian Journal of Social Sciences, 4(1), 33-43.

Zakaria, S. M., \& Tauhaid, N. S. M. (2018). Cabaran Membesarkan Anak-Anak Autisme Daripada Perspektif Ibu (The Challenges Of Nurturing Autistic Children From The Mother's Perspective). Jurnal Psikologi Malaysia, 32(1), 58-71.

Sitimin, S. A., Fikry, A., Ismail, Z., \& Hussein, N. (2017). Work-family conflict among working parents of children with autism in Malaysia. Procedia Computer Science, 105, 345-352.

Takom, L., Bahari, F., \& Nawi, N. H. M. (2015). Kajian awal mengenai penerokaan faktor kemurungan dan kebimbangan dalam kalangan ibu bapa kanak-kanak kurang upaya (Preliminary studies on the exploration of factors of depression and anxiety among parents of children with disabilities) [Paper Presentation]. Malaysia International Psychology Congress (Malaysia).(pp 112-117). Persatuan Psikologi Manusia.

Ubeh, C., Bahari, F., \& Voo, P. S. K. (2017). Kesejahteraan Subjektif Ibu Bapa Kanak-Kanak Kurang Upaya Pembelajaran: Pengaruh Komitmen Keagamaan, Harapan Terhadap Anak, Dan Sokongan Sosial (Subjective Well-Being Among Parents Of Children With Learning Disability: The Effect Of Religious Commitment, Parents Hope For Child, And Social Support). Jurnal Psikologi Malaysia, 31(2), 45-56.

Wa-Mbaleka, S. (2019). Ethics in Qualitative Research: A Practical Guide. International Forum Journal, 22(2), 116-132.

World Health Organization. (2021). Autism Spectrum Disorders. https://www.who.int/newsroom/fact-sheets/detail/autism-spectrum-disorders 
Zainun, Z., Masnan, A. H., Bakri, A. Z. A., Aspani, S. A., Hassan, N. A., \& Zawawi, Z. (2019). Pengetahuan, sikap dan persepsi masyarakat tentang kanak-kanak Autism Spectrum Disorder (ASD) (Knowledge, Attitude and Social Perception of Autism Spectrum Disorder (ASD) Children). Southeast Asia Early Childhood, 8 (1),19-29. 